\title{
RELAÇÃO ENTRE DESSECAÇÃO E COMPRIMENTO DO QUELÍPODO EM ESPÉCIES IRMÃS DE CARANGUEJOS CHAMA-MARÉ (MINUCA BURGERSI E MINUCA MORDAX)
}

\author{
Borges, D.J. ${ }^{1}$; Rodrigues, R.O. ${ }^{2, *} \&$ Costa, T.M. ${ }^{1}$ \\ ${ }^{1}$ Universidade Estadual Paulista (UNESP), Campus do Litoral Paulista. Laboratório de Ecologia e Comportamento Animal. \\ ${ }^{2}$ Programa de Pós-Graduação em Ciências Biológicas (Zoologia), Universidade Estadual Paulista (UNESP), Campus de Botucatu. \\ Laboratório de Ecologia e Comportamento Animal. \\ *Autor correspondente: renata.rodrigues@unesp.br
}

\begin{abstract}
Caranguejos chama-maré estão expostos a uma grande variedade de processos físicos e químicos em zonas intertidais. Em temperaturas elevadas do ar, esses caranguejos aumentam a taxa de transpiração para transferir calor do corpo para o ar, diminuindo a temperatura corporal. Alguns comportamentos e órgãos ajudam a diminuir a temperatura corporal, mas a água perdida no processo de dessecação somente será restaurada pelo contato do animal com a água ou com o substrato. Assim, o objetivo deste trabalho foi avaliar o efeito temporal da temperatura na perda e no ganho d'água em machos de caranguejos chama-maré (Minuca burgersi e Minuca mordax), considerando o tamanho do quelípodo hipertrofiado (comprimento do própodo). Para tal, indivíduos das duas espécies foram coletados em dois estuários do Estado de São Paulo (Rio Verde, Iguape e Rio Itapanhaú, Bertioga) e, em seguida, foram levados ao laboratório. Após 48 horas, foram colocados separadamente em uma estufa, a $30^{\circ} \mathrm{C}$, sem água e sem sedimento disponível, durante 2 horas. O padrão da perda d'água foi observado através da diferença de peso entre o tempo inicial, 15 minutos após o início, a cada 30 minutos após o início e ao final do experimento. Logo após, água foi adicionada ao recipiente de cada caranguejo para observar o ganho de água ao final do mesmo período. Populações da mesma espécie não diferiram quanto à perda d'água (GLM, $P=0,471)$, à reidratação (GLM, $P=0,576)$ e ao comprimento do quelípodo (GLM, $P=0,330)$. Comparadas às espécies, $M$. burgersi perdeu mais água (GLM, $P=0,000)$ e apresentou quelípodo menor (GLM, $P=0,000$ ). Entretanto, ambas apresentaram perda d'água maior nos primeiros 15 e 30 minutos de experimento (GLM, $P=0,000)$, e reidrataram-se igualmente após o período de dessecação (GLM, $P>0,05)$. Por fim, indivíduos com quelípodos maiores perderam menos água (Teste de correlação de Spearman, $r=-0.908, P=0,000$ ), mas reidrataram-se igualmente (Teste de correlação de Spearman, $r=-0.184, P=0,109$ ). Estes resultados sugerem que, apesar de ambas as espécies responderem diferentemente ao estresse térmico, o tamanho do quelípodo pode ser o principal fator de prevenção à desecação.
\end{abstract}

Palavras-chave: desidratação, estuários, reidratação, termorregulação. 